\title{
3. Long-term Economic Mobility and the Private Sector in Developing Countries: New Evidence
}

The debate over economic growth and economic mobility continues to rage. On the positive side, ample studies have shown that when economic growth has taken place, poverty has fallen; when poverty has not fallen, it typically is because economic growth has not taken place (Dollar and Kraay 2001; Fields 2001). "A world free of poverty" is the mission of the World Bank; for its part, the International Finance Corporation (IFC) seeks to "promote private sector investment in developing countries, which will reduce poverty and improve people's lives.'The IFC has long placed improved investment climate at the core of its economic development activities. In a series of speeches, Nicholas Stern, chief economist of the World Bank, has emphasized the linkage between private sector development and poverty reduction. Summing up the findings from a large body of research, Stern has said, "The investment climate - urban and rural, at both the national and state level-is key to achieving sustained poverty reduction" (Stern 2001).

Not everyone shares this view. People are literally casting stones at the World Bank, the IFC, the International Monetary Fund, and other organizations whose activities, they believe, are harmful to the poor. Skeptics argue that the labor force has failed to share in the gains from economic growth. According to them, workers in developing countries lack the rights, legal protection, and union representation to participate in any of the benefits of economic growth.

It is said that multinational firms exploit their workers and their wages do not rise, even with an increase in demand for their work; that globalization makes some 
people who are already rich even richer by keeping the poor in poverty; and that economic growth is good for companies and bad for workers. The argument is that growth that is driven by trade or investment gives Western multinationals a major role in the development of the country, and these big firms are interested only in profits and not in the well-being of the people. ${ }^{2}$ One critic (Gindin 2002: 5) proclaims, "Where growth has come, it has come not with a general improvement in social justice but with costs in terms of internal democracy, human rights, and equality. In the mid-fifties, a Latin American general, when asked about economic development in his country, responded with words that still capture so much of the present reality in third world so-called success stories like Brazil and Mexico: 'The economy is doing great, but the people in it aren't." Another critic (Henwood 1996:4) states, "The antiglobalizers are right that economic growth doesn't necessarily make people happier, and often makes them miserable; that institutions like the World Bank have made the rich richer while making the nonrich poorer; that conventional ideas of free trade are wonderful for managers and stockholders, but hell on workers and nature; and that a turn away from the accumulation of things and toward more humane pursuits would be highly welcome." All these forces are alleged to have become even more powerful during the heightened globalization of recent years. As Jagdish Bhagwati (2002: 2) puts it, "Globalization's enemies see it as the worldwide extension of capitalism, with multinational corporations as its far-ranging B-52s."

This chapter builds a new data base and presents evidence for judging among these competing views. We provide fresh, detailed evidence on long-term economic mobility and market-oriented economic growth in four economies: Taiwan (China), Indonesia, Costa Rica, and Brazil. (Because of the absence of suitable data sources for African countries and transition economies over the long term, we could not include any of these countries in our study.) In this study, "long-term economic mobility" refers to the structural changes that take place over time, producing improvements or deteriorations in key indicators of economic status for successive cohorts of individuals.

Consistent with the mainstream view of economic growth as a factor promoting long-term economic mobility, we hypothesize that those economies in which economic growth has been most rapid are precisely the ones that have achieved the greatest progress toward poverty reduction through improved labor market conditions, especially in private employment. We also hypothesize that the positive relationship running from economic growth through the labor market to poverty reduction continued to hold in the 1990s in essentially the same way as in earlier years when globalization was less intense. Both hypotheses are confirmed by our data. Our results therefore cast doubt on two claims: that workers are being left out of economic growth today, and that workers participated in economic growth before but are not able to do so now.

\section{CONTRIBUTIONS, METHODS, AND HYPOTHESES}

The International Finance Corporation's publication Paths Out of Poverty (2000) lays out the rationale for the IFC's work on poverty reduction. Paths Out of Poverty looks 
for the actual, concrete mechanisms for escaping from poverty. The focus is on the role of the private sector. In a healthy business environment, spurred on by competition and with appropriate support from the government, private enterprise can be a significant source of upward mobility and poverty reduction, generating employment and tax revenue, increasing investment, and encouraging innovation, openness to ideas, and empowerment. The study finds a clear mutuality of interests among private enterprises - whether large, medium, or small-government, and the poor.

As a follow-on to Paths Out of Poverty, it is desirable to explore further the links between the business environment and poverty reduction, a subject that has been largely neglected in the economics literature. While it is clear to all that what ultimately matters is long-term reduction in poverty rates and not just short-term transitions, surprisingly little empirical work has been done on the proximate causes of poverty reduction. Long-term economic growth of course matters, but what are the actual, precise mechanisms by which people move out of poverty as the economy grows?

It is useful to think of people benefiting from economic growth in two ways: in their capacities as consumers and in their capacities as workers. In their capacities as consumers and by virtue of their citizenship (or residence) in growing economies, people are provided with valuable goods and services, including food, housing, and health care. Furthermore, in their capacities as workers, people may benefit from economic growth by improved types of participation in the labor market. In these two ways, the fruits of economic growth may be spread so as to enable people to lead better lives. If these views are correct, we would expect to find that those countries that had introduced and maintained successful growth-oriented policies would be the ones that achieved more rapid and sustained improvements in standards of living for people both as consumers and as workers. Many years ago, Walter Galenson (1977: 21-22) captured this view perfectly: "Rapid sustained growth has had positive effects on the living standards of all economic groups of those countries that experienced it... Growth has not 'failed'; there has simply not been enough of it in the great majority of less developed nations."

The World Development Report 2000/2001 dealt at length with improvements in the lives of people as consumers, but gave much less attention to the long-term effects of economic growth on changes in opportunities for people as workers. The report put forth a three-part program for attacking poverty through opportunity, empowerment, and security; however, the report had little to say about what promotes upward mobility in the longer term. In contrast, the World Development Report 1990 urged policies making fuller use of the poor's most abundant asset: their labor. The Bank's 1993 study, The East Asian Miracle, included a section on the contribution of that region's efficient labor markets to rapid economic growth, and the World Development Report 1995 looked specifically at "Workers in an Integrating World." The 1995 World Development Report maintains that economic growth delivers higher wages and encourages workers to move to better paying and higher productivity jobs in the formal sector. Specifically, the report states (p. 3): "Growth has reduced poverty through rising employment, increased labor productivity, and higher real 
wages. Growth also tends to reduce poverty and inequality, including inequality between men and women. For today's low- and middle-income countries, the fear that growth will primarily benefit capital, create few jobs, and fail to raise wages is unfounded."

Development economics offers a long and distinguished history of research on how labor market conditions change in the course of economic growth. The Nobel Prizewinning work of W. Arthur Lewis (1954) and subsequent amplifications by John Fei and Gustav Ranis (1964) hypothesized that economic growth may lead first to an increase in the share of the labor force in relatively well-paid jobs and then, once the labor surplus is exhausted, to rising real earnings levels among a close-to-fully employed labor force, enabling people to use their improved labor incomes to buy valued goods and services. Earlier work by Fields (1984,1985, 1994) confirmed this pattern empirically in the rapidly growing economies of East Asia.

What is missing thus far are original country studies focusing on long-term economic mobility in developing countries running up to the present. As used in this study, "longterm economic mobility" is the upward or downward change in real incomes and other indicators of economic well being, such as employment status. This is to be distinguished from such other aspects of economic mobility as the amplitude of income fluctuations ("non-directional income movement" or "flux"), the percentage of people who change income quintile/decile/percentile ("positional movement"), the change in people's shares of total income ("share movement"), and the correlation between income at an earlier date and income now ("time-dependence"). We concentrate here on directional movements in income and other indicators, because of the clear welfare significance that these have (Fields 2001).

The aspects of long-term economic mobility that we will investigate are the gains or losses in income and other indicators experienced over the course of decades. Because of lack of data, we will not be looking at the changes in permanent incomes of individuals in the course of their life cycles or individuals' incomes today, compared to incomes a generation or two ago. The ideal way to study long-term economic mobility would be to compare the economic situations of particular individuals now with their own economic situations decades ago. To do this on a country level, we would need a national panel survey conducted over many years, such as the Panel Study of Income Dynamics in the United States, which started with 5,000 American families in 1969 and has traced the original people who remain in the same families, those who split and formed new families, those who were born, and those who died. No developing country in the world offers such a data set. In the absence of such data, the next best way to investigate long-term economic mobility is to compare conditions for today's generation with those of a previous one using comparable surveys at the national level.

Thus, the questions we want to look at for the selected countries are these: In the last 20 or 30 years, by how much have incomes risen and for whom? Are more people working now than before and are they working in better jobs? What has happened to poverty and inequality over time? What role has the development of the private sector played in the long-term economic mobility of these countries? 
No comprehensive database is available for answering such questions, and so a substantial investment in data preparation is required. The best data that exist now are in the "Database of Labor Market Indicators across Countries," being prepared by Martin Rama and Raquel Artecona (forthcoming) at the World Bank. Information is being compiled on a wide range of variables (labor force and participation rates, employment and unemployment, wages and productivity, conditions of work and benefits, trade unions and collective bargaining, public sector employment, and labor standards) for 121 countries, both developed and developing. This database is still under construction, and no analysis of the data has appeared to date. Accordingly, to assemble the information needed to answer the questions posed in this study, we have had to conduct meticulous within-country work.

In each case, the high-quality household surveys that have been conducted over decades are examined: the manpower utilization surveys and surveys of family income and expenditure in Taiwan, the SUSENAS and SAKERNAS surveys in Indonesia, the National Household Surveys in Costa Rica, and the PNAD surveys in Brazil. These surveys have generally been conducted using consistent sampling frames and questions so that the results are comparable over time; when changes have been made rendering certain series incomparable, we noted these in the data documentation. Because these surveys include labor market data solely or primarily, the focus of our work will be on changes in employment and labor earnings.

Compiling the data from these various surveys proved to be a laborious undertaking, because the information is presented in scattered sources, often on year-by-year basis, and more often than not in a form that requires extensive additional calculations. In this chapter, we present figures depicting the changes in a number of labor market indicators that took place in each country over the course of decades (see Appendices A-D). A detailed data appendix with tables, definitions, and sources is available from the authors upon request.

We hypothesize that economic growth would affect poverty in the following ways:

\section{Hypothesis 1}

Open unemployment falls until essentially full employment is attained. By international agreement, a worker is defined to be "openly unemployed" if he or she did not work even one hour for pay in the preceding week or month but was actively looking for work. In economies without strong social safety nets, few people can afford to be entirely without work for any length of time, and therefore open unemployment is only the tip of the proverbial employment problem iceberg.

\section{Hypothesis 2}

The composition of employment improves, shifting away from low productivity sectors, occupations, and occupational positions. Specifically, we expect that:

Hypothesis $2 a$ A falling percentage of workers will be employed in agriculture. (This is a positive development because agriculture is typically the lowest-paying sector in a developing economy.) 
Hypothesis $2 b$ A growing percentage of workers will be employed in wage and salary jobs. (This is an improvement, because in many countries but by no means all, these jobs pay better than self-employment and unpaid family work.) (For a discussion of this issue, see the chapter by William Maloney in this volume.)

Hypothesis 2c A growing percentage of workers will be employed in professional and other high-level occupations. (These are the best-paying jobs in the economy.)

Hypothesis $2 d$ A smaller percentage of workers will have low levels of education. (This is good, because workers with more education earn more.)

Hypothesis $2 e$ A rising percentage of workers will be employed in the private sector. This would point to the private sector as the source of dynamism in the economy.

\section{Hypothesis 3}

Real earnings rise overall, for both female and male workers, in various industries, and in both the public and private sectors.

Hypothesis 4

As a consequence of the outcomes of Hypotheses 1-3, poverty will fall.

\section{Hypothesis 5}

Inequality may or may not fall. We offer no specific hypothesis about inequality, because empirical research has shown that inequality in developing countries rises as often as it falls, and the rise or fall is not significantly related to the rate of economic growth (Fields 2001).

\section{THE FOUR COUNTRY CASES}

What does the actual experience of the four very different economies we study indicate about our hypotheses? We turn now to an investigation of the countries.

\section{The Case of Taiwan (China)}

The Newly Industrialized Economies (NIEs) of Taiwan (China), Hong Kong, Singapore, and South Korea have been labeled the "Four Tigers" because of their strong economic performance. (For more on South Korea, see the chapter by Se-Il Park in this volume.) Taiwan, in particular, has had spectacular growth over the past 30 years; per capita real GNP has increased seven-fold over that period.

In past studies, Gary Fields $(1984,1985,1994)$ has used data from Taiwan's manpower utilization surveys and surveys of family income and expenditure to test the preceding five hypotheses for Taiwan for earlier dates. The general finding is that Taiwan grew rapidly and the labor force benefited greatly from that growth in the hypothesized ways. Combining these time series and' updating them up to the year 2000, we find that labor market conditions in Taiwan continued to improve with economic growth. (See Appendix A for detailed information about growth, 
unemployment, employment composition, real earnings, and poverty and inequality in Taiwan). The unemployment rate, though higher than before, has never exceeded 3 percent. The composition of employment improved. Agricultural employment fell from 37 percent of total employment in 1970 to less than 8 percent today. Paid employment as opposed to self-employment and unpaid family work grew from 51 percent of total employment to 71 percent. Professionals as a percentage of total employment went up from 15 percent in 1970 to 38 percent in 2000 . The lower education group plummeted; those with less than a secondary education fell from 74 percent to 18 percent of the employed population in 30 years.

The powerhouse behind the growth of employment in Taiwan's labor market was the private sector. Consider three groups of workers: wage and salary employees in the public sector, wage and salary employees in the private sector, and self-employed and other workers in the private sector. Between 1970 and 2000, the number of wage and salary employees in the public sector fell, implying that all the growth in employment was in the private sector. Within the private sector, wage and salary employment grew at the expense of self-employment and other types of work.

Real earnings rose overall, for both men and women, and for every industrial grouping and sector. Although real earnings have risen, they have not seen the phenomenal growth in the 1990s that occurred in the 1980s. Workers' wages in Taiwan grew at a slightly higher rate than the economy's growth rate in the 1980 s. This was not the case in the 1990s: GNP per capita grew by 68 percent in real terms, while real earnings grew by 33 percent. Disaggregating, we find that the earnings gap between male and females fell throughout the 1990s. In 1990, females' real earnings were 67 percent of males'. By 2000 , their earnings were 74 percent of males'. Earnings increased in each sector (community, social, and personal services; manufacturing; and trade). Public sector earnings remain only somewhat above average, as was the case 20 years ago, confirming Taiwan's position as one of the most highly integrated labor markets in the world.

The reduction of poverty has been outstanding throughout Taiwan's history of economic growth. The estimated percentage of households with disposable incomes less than NT $\$ 200,000$ in 1980 prices was 47 percent in 1980 and just 11-12 percent in the late 1990s.

Finally, income inequality has been slowly and steadily rising since 1980 . Nonetheless, Taiwan today still has one of the most equal distributions of income of any economy in the world.

In summary, the economic growth that has taken place in Taiwan was passed on to workers in the form of continued close-to-full employment, higher wages, improvements in the job mix, a better-educated work force, and a reduction in poverty. Economic growth in Taiwan continued to promote long-term economic mobility in the 1990 s, just as in the previous decades.

\section{The Case of Indonesia}

Indonesia has been labeled one of the "Asian Cubs" for its strong performance in sustained economic growth. During the three decades prior to the economic crisis of 1997-98, real GNP per capita in Indonesia grew on average by 4.5 percent a year. 
To investigate to what extent Indonesia's economic growth was passed on to the workers, we divide our analysis into the strong growth period up to 1997 , the economic crisis in mid-1997 that led to the massive fall of GDP per capita in 1998, and the attempted recovery since (see Appendix B).

The Central Bureau of Statistics (BPS) conducts a household survey called SAKERNAS, or the National Labor Force Survey, from which the official labor market statistics are derived. For the most part, the data are comparable over time. One substantial change was made in 1998, however; the minimum age for the survey was raised from 10 to 15 years old.

When Indonesia's period of strong economic growth began, essentially full employment had already been attained. Unemployment hovered between 2 and 3 percent until the crisis, then jumped to 6 percent in 1999. Improvements in labor market conditions in Indonesian economic growth were reflected not in open unemployment but in employment composition, which exhibited sharp improvements. Workers shifted away from low productivity agriculture and into higher paying sectors. In 1976,62 percent of total employment was in the agricultural sector. By 1997, the percentage of agricultural workers had declined to 41 percent. From 1986 to 1997, industrial employment more than doubled, from 8 percent to 19 percent of the labor force (Smith and others 2000). Professional employment also grew. In 1976, 5 percent of total employment was in professional occupations. By 1997, the percentage had increased to 9 percent. As a result of the shift away from agricultural employment and into industrial and professional jobs, employment in the formal wage sector went up. The work force has also become more educated, as the percentage of employed persons with less than a secondary education has decreased from 91 percent in 1976 to 67 percent in 1997. All these improvements reflected the pull of workers into growing sectors of the economy, with consequent rising real earnings not only in the sectors they were moving to but in the sectors that they were leaving (see discussion below).

Statistical data on wages reveal that workers have benefited from economic growth. The statistical authorities do not publish data on real wages. We converted the nominal earnings to real earnings using the Consumer Price Index from the IMF, which covers only urban prices. Real earnings rose for males, females, and each main industry during the 1990s until 1998. From 1991 to 1997, real earnings grew by around 47 percent, which was faster than the growth rate of the economy. Employees earnings in manufacturing grew by 51 percent, as compared with 38 percent for workers in agriculture and 29 percent for workers in trade. Thus, the workers of Indonesia benefited with higher earnings from the economic growth of the early and mid-1990s.

The rapid economic growth since the late 1960s had a major effect on poverty. In 1976 , the incidence of poverty was around 40 percent of the population. By 1996, the percentage of the population below the poverty line had fallen to 11 percent. There was no pronounced trend in inequality over this period.

Overall, then, workers benefited from the positive economic growth in Indonesia through 1997. The employment composition improved, the work force became more educated, real earnings went up for males and females and in each sector, and 
poverty fell significantly. The only negative feature was the increase in open unemployment by 3 percentage points, which is dwarfed by the 47 percent increase in real earnings.

Although this is a study of long-term economic mobility, we would be remiss if we did not talk about economic events in Indonesia in the last few years. After more than a quarter of a century of sustained economic growth, a major economic crisis hit Indonesia in the middle of 1997. The crisis was extremely severe, causing a 15 percent contraction in real GDP per capita in 1998 and a fall in the rupiah to one-quarter of its 1997 value.

How did the economic crisis affect the composition of employment? What happened to the labor market because of this huge economic decline?

During the Indonesian economic crisis, the unemployment rate increased, but only from 4.7 percent in 1997 to 5.5 percent in 1998 and 6.4 percent in 1999. The impact of the crisis on the labor market was not felt as harshly on employment as it was on earnings. The reason massive unemployment did not occur was because of the flexibility of the Indonesian labor market to take in displaced workers. During economic decline, the employment structure would be expected to shift back into less productive and lower paying sectors and occupations. This is exactly what happened during the Indonesian crisis. Displaced workers from the more productive sectors, occupations, and occupational positions were forced to find jobs in the low-paying agricultural and informal sectors. Agricultural employment increased by almost 5 million workers, raising agriculture's share of total employment from 41 percent in 1997 to 45 percent in 1998. About half consisted of workers from other sectors; the other half, of new entrants to the labor force (ILO 1999). Wage and salaried employees as a percentage of total employment decreased from 35 percent in 1997 to 33 percent in 1998. Wages during the economic crisis fell dramatically. "The drama of the crisis lies not in employment but in earnings," Duncan Thomas and his colleagues note (Thomas, Beegle, and Frankenberg 2000: 16). Real earnings for both males and females decreased by about 40 percent from 1997 to August of 1998, according to an ILO study (1999). Real hourly earnings during the crisis collapsed by around 40 percent in one year, James P. Smith and his colleagues found (Smith and others 2000). This study also noted that real hourly earnings of self-employed males in the rural areas have remained essentially stable. These workers account for one-quarter of the male work force in Indonesia; thus conclusions about the effects of the crisis on earnings that focus only on the market wage significantly overstate the magnitude of the crisis (Smith and others 2000).

The crisis reversed the substantial gains that Indonesia had made throughout the years in poverty reduction. By one estimate, in 1996, 11 percent of the populace was living in poverty; but because of the crisis, the poverty rates more than doubled to 24 percent (Smith and others 2000). By another estimate using a different methodology, the poverty rate rose from 18 percent in 1996 to 27 percent in 1999 (Suryahadi and others 2000). This is what would be expected from the decrease in real wages, worsening of the employment structure, and increase in people out of work. Since the Gini coefficient of expenditure was 0.36 in 1996 and 0.31 in 1999 , it would seem that the crisis has fallen disproportionately on higher income people. 
As this chapter is being written, the latest figures show an unemployment rate of 8.1 percent, 60 percent of the population living below a poverty line of \$US2 a day, and dubious economic prospects. Poverty remains substantially higher than it was immediately before the crisis (Suryahadi and others 2000). The workers in Indonesia are continuing to suffer from the doldrums the economy is facing.

\section{The Case of Costa Rica}

This study uses statistical data obtained from the household survey in Costa Rica, first called the Encuesta Nacional de Hogares, Empleo y Desempleo and later the Encuesta de Hogares de Propósitos Múltiples. Data on labor market conditions in Costa Rica date back to 1976 . However, because of a change in the survey format, data after 1986 are not strictly comparable to earlier ones. (See Appendix $C$ for detailed information about growth, unemployment, employment composition, real earnings, and poverty and inequality in Costa Rica.)

Costa Rica exhibited economic growth in the 1970 s, recession in the early 1980 s, and uneven but generally positive growth since. Growth has never been rapid, so it would be expected that labor market conditions would not have changed much either.

In many respects, that is in fact the case. The unemployment rate doubled in the 1981 recession, then gradually came down; since 1987, it has been little changed. The movements of workers out of agriculture and out of the low education categories have continued, at similar rates in the 1976-86 and 1987-2000 periods. The labor force moved gradually into wage and salaried employment, but that trend stopped in the late 1980s. On the other hand, the growth of professional employment continued at the same pace in the later period as in the earlier one.

For a long time, the Costa Rican labor market has been characterized as a segmented one, in which wages in the public sector are substantially higher than those in the private sector (Gindling 1991). Interestingly, since 1987, the public sector has been shrinking in relative size, though its wage advantage has changed little. Most Costa Rican employment growth has taken place in the private sector, and this trend has accelerated in the latter period as compared to the earlier one.

During the lost decade of the 1980s, real incomes stagnated. Since then, they have slowly been rising: overall; for men and for women; in both the public and the private sectors; and in each sector (manufacturing, commerce, agriculture, and services).

Poverty rates rose during the recession of the 1980s, then started falling. That trend has continued unabated since 1987 , according to both government and Inter-American Development Bank estimates. Inequality appears to have fallen in the 1976-86 period and to have remained unchanged since.

In sum, when there was economic growth in Costa Rica, workers benefited. The economic growth that occurred was transmitted through the labor market with a movement to higher paying jobs, substantial increases in real income, decreases in unemployment, and lower poverty. The rise in earnings has been comparable to the rise in GDP. 


\section{The Case of Brazil}

This study is based on data on labor markets and income distribution derived from the Pesquisa Nacional Por Amostra de Domicilios (PNAD). Surveys were conducted annually during the 1990s (excluding the years 1991 and 1994, when there were no surveys). After 1990, the PNAD was revised, which introduced many changes in the survey. Because of these changes, it would not be appropriate to compare pre- and post-1990 statistical data directly. (See Appendix D for detailed information about growth, unemployment, employment composition, real earnings, and poverty and inequality in Brazil.)

Like other Latin American countries, Brazil experienced positive real per capita GDP growth in the 1970s, stagnation in the 1980s, and slow growth in the 1990s. Unfortunately, the unemployment rate did not fall during either growth period. However, the job mix did improve, as the share of employed persons in professional employment rose and the share in agriculture fell. The fraction of workers with low education fell, but remains disturbingly high.

Based on special tabulations from the PNAD, generously prepared for us by Sergei Soares of Instituto de Pesquisa Econômica Aplicada, we were able to examine the changes in different types of employment in the stagnation years of the 1980s and again during the growth years of the 1990s. In both periods, public sector contract employment grew faster than did private sector contract employment and informal sector employment. The Brazilian labor market is said to have exhibited "tremendous flexibility" overall, but the government's employment policy is charitably said to have been "generous" (Fox, Amadeo, and Camargo 1994: 159-60). Based on these figures and characterizations, we conclude that the public sector played a disproportionate role in the small improvements that took place in the Brazilian labor market. Nonetheless, because formal public employment is only a small fraction of total employment, most of the job growth in Brazil was in the private sector; within that, most of the growth was in informal employment. This reflects a region-wide phenomenon. In Latin America during the 1990s, seven of every ten new jobs in cities were generated in the informal sector (ECLAC 2001).

Earnings data in Brazil are problematic, because of the hyperinflation that took place in many years and the inability to adjust the nominal wage series by a CPI pertaining to the precise month (or even week) when the survey was conducted. Nevertheless, looking at broad trends, we see somewhat positive earnings growth in the 1980s and substantially positive earnings growth in the 1990s. The gender pay gap has been contracting, a progressive development. On the other hand, real earnings, which were already higher in the public sector than elsewhere, grew even faster than in the private sector-a sign of deepening labor market segmentation.

The 1980s were a time of rising poverty, owing to an increase in the already high income inequality in Brazil and the slow economic growth registered during that time (Londoño and Székely 1998). In the 1990s, though, growth has been more rapid, poverty has been falling (Székely 2001), and inequality has stopped rising. Still, the 
poverty rates reported for Brazil for the 1990s are considerably higher than those reported for the 1970s and early 1980 s.

In summary, the Brazilian labor market did not improve much, mainly because the economy did not achieve much growth and because what small gains there were tended to be quite unequally distributed.

\section{LESSONS LEARNED FROM THE COUNTRY STUDIES}

A comparison of the four country studies yields some powerful findings. Economic growth has been the driving force leading to improved labor market conditions and therefore to reductions in poverty. Moreover, the faster the economic growth, the faster the fall in poverty.

Taiwan was the fastest growing country, and it eliminated 75 percent of its poverty in 14 years of rapid economic growth, achieving a 5.4 percent annual reduction in the poverty rate. Indonesia pre-crisis was able to reduce its poverty rate by almost as much: 72 percent. Because of slower growth, however, its annual rate of poverty reduction was a more modest 3.6 percent. Sadly, poverty rates fell by much less in Costa Rica (2.1 percent a year, by one estimate; 1.5 percent, by another) and have not fallen at all in Brazil since the 1980s. Slow economic growth has been the culprit in both these economies. Although the importance of economic growth for poverty reduction is not a new finding, it reinforces various past studies and casts doubt on the view held in some quarters that in today's globalized world, economic growth no longer leads to poverty reduction.

Economic growth brought about higher wages, a movement to more productive and higher paying jobs, and a more educated labor force in each country we studied. Our data confirm the general hypothesis that the labor market plays a critical role in transmitting economic growth or responding to the lack of such growth. Furthermore, this relationship remained the same in the 1990 s as in previous decades. Our analysis indicates that labor market conditions improved during economic growth and worsened during economic decline. The countries that had sustained rapid growth (Taiwan and Indonesia) had much more favorable results in their labor markets than the slowergrowing countries (Costa Rica and Brazil). Unemployment rates typically fell during periods of economic growth, except when there was virtually full employment to begin with.

In times of economic decline, the labor markets responded with lower wages, a movement of workers back into less productive sectors and types of jobs, and higher unemployment rates. The recession of the 1990 s had different impacts in different countries. The economic crisis that hit Indonesia affected the labor market mainly through a deterioration in wages; unemployment increased only slightly, considering the severity of the downturn. This was because Indonesia's labor market was flexiblea flexibility that enabled many displaced workers to be absorbed into the agricultural sector.

The respective role played by the private and public sectors in employment was an important factor in the long-term economic mobility of the four countries. Of, the four countries, Taiwan comes the closest to a non-dualistic labor market. There, the engine of growth in employment was the private sector. In Indonesia, most workers are employed in the 
private sector, and the percentage of employees who worked as civil servants decreased. From these facts, we conclude that the private sector was the stimulator of employment growth in Indonesia. In Costa Rica, the public sector pays much higher wages than the private sector does (close to double). However, the private sector had higher rates of employment growth during the 1990s, thereby facilitating the upward mobility of the workers in the country. On the other hand, Brazil's public sector played a disproportionate role in the gains in the labor market. During the 1990s, public sector employment and earnings growth were both higher than the private sector, but the private sector remained the predominant employer in the country.

Returning to the controversy with which this chapter began, there are those who say that workers will participate in the growth process through heightened demand for labor by successful firms. Others argue the opposite: that nowadays, it is impossible to continue to progress in such a way, because fierce competition imposes incessant cost pressures on the labor market, preventing earnings from rising and poverty reduction from taking place.

These results deliver a clear verdict. We reaffirm the position that now, as before, economic growth is a critical means for improving employment and earning opportunities and thereby lowering poverty.

Before closing, we wish to raise a cautionary note. Let us not forget that although economic growth tends to benefit labor market conditions and reduce poverty overall, not every worker in a growing economy is expected to be better off. Even when economic growth is very fast, there will always be some workers who will lose their jobs or suffer declines in earnings and end up worse off. These people should not be ignored. 


\section{APPENDIX A. THE CASE OF TATWAN (CHINA)}

Source: All figures for Taiwan are based on authors' calculations, drawing on Taiwan's Manpower Utilization Surveys and Surveys of Family Income and Expenditure. Earlier years' figures were published in Fields $(1984,1985,1994)$.
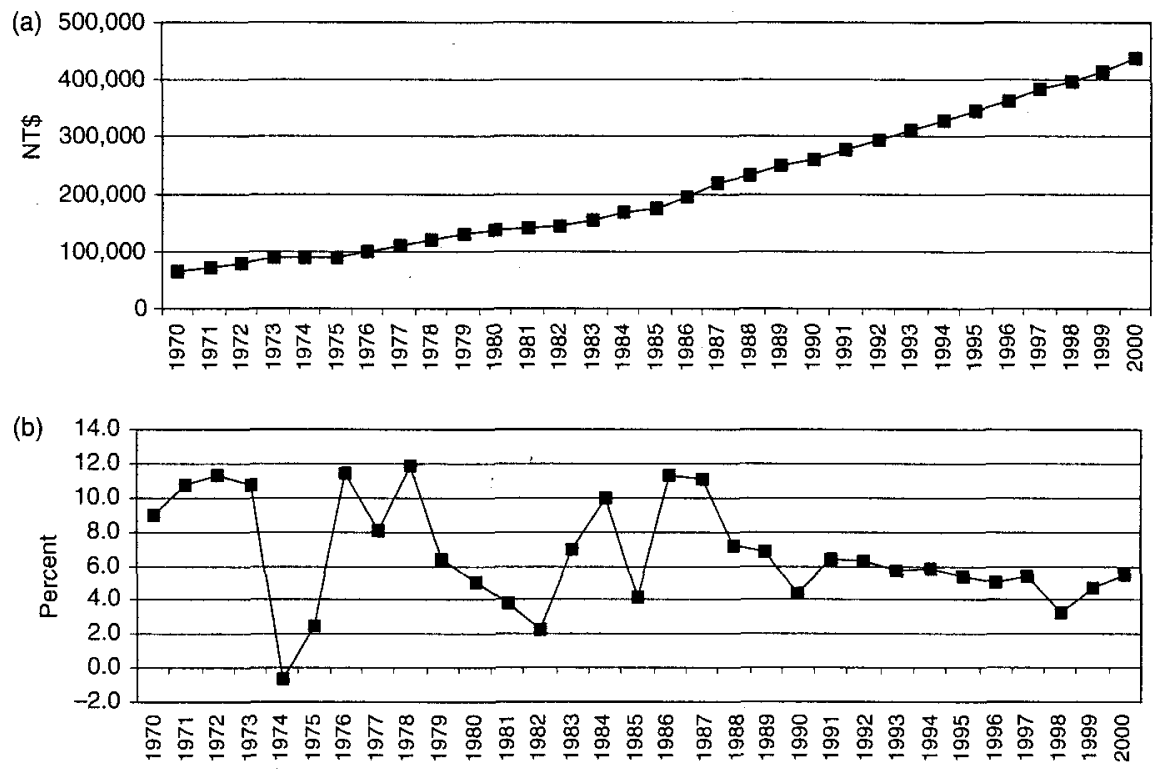

Figure 3A-1. Growth. (a) Level of Real GNP/Capita, 1970-2000 (NT dollars); (b) Growth of Real GNP/Capita, 1970-2000 (percent).

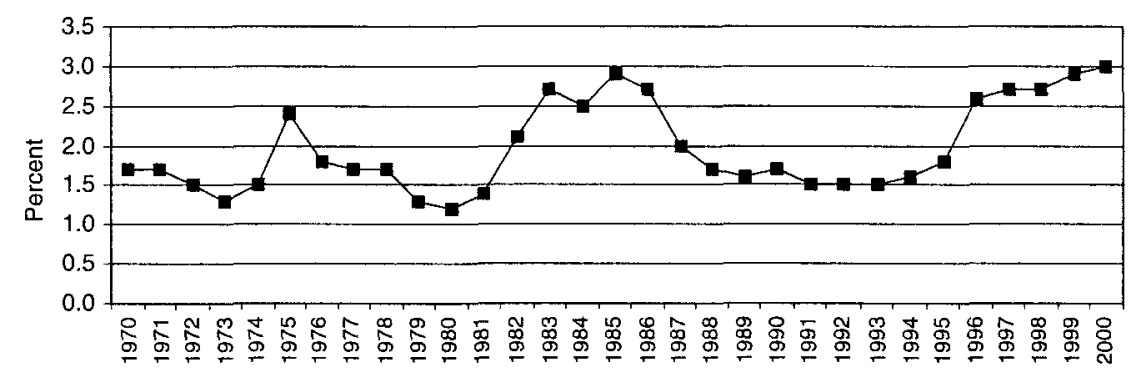

Figure 3A-2. Unemployment Rate, 1970-2000 (percent). 
(a)

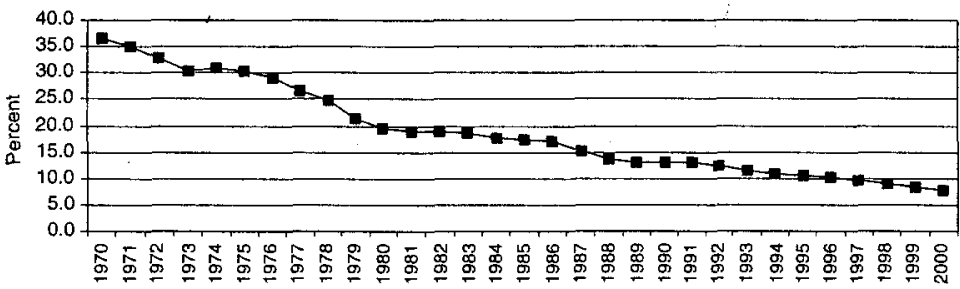

(b)

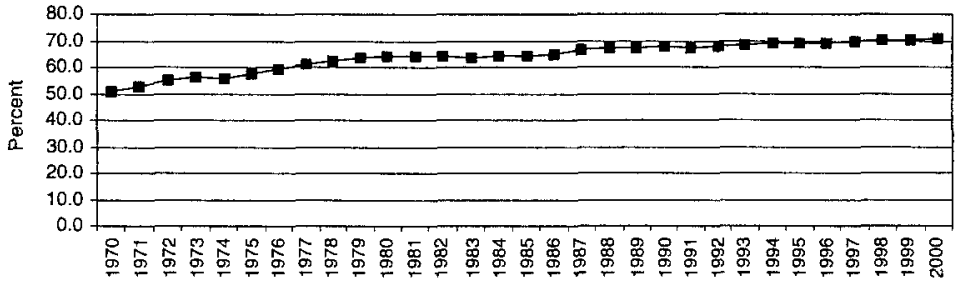

(c)

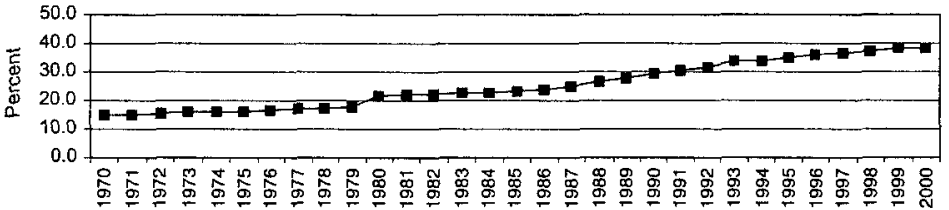

(d)

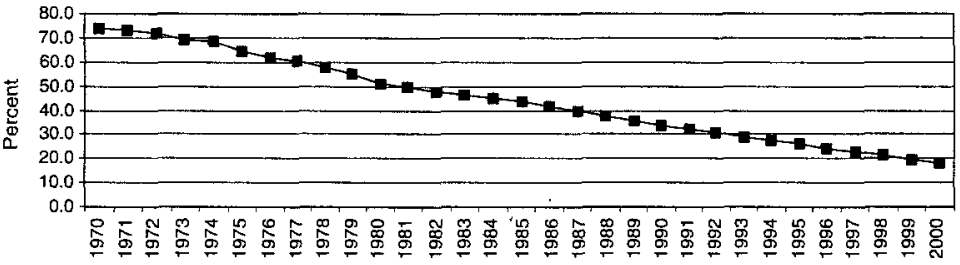

(e)

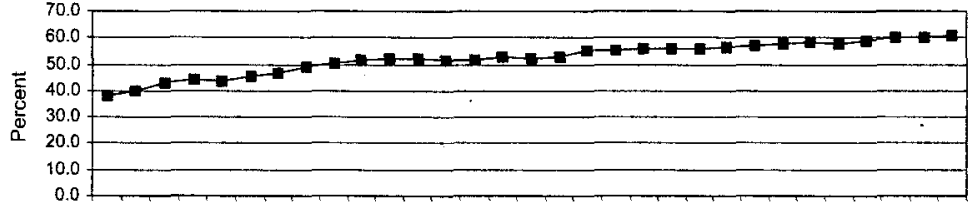

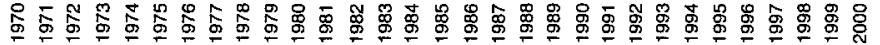

(f)

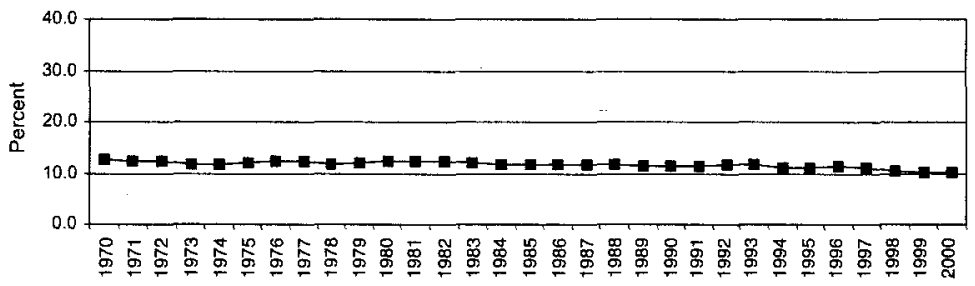

Figure 3A-3. Employment Composition. (a) Agricultural Employment as a Percentage of Total Employment, 1970-2000 (percent); (b) Paid Employees as a Percentage of Total Employment, 1970-2000 (percent); (c) Professional, Managerial, and Clerical Personnel as a Percentage of Total Employment, 1970-2000 (percent); (d) Percentage of Employed Persons with Less than a Secondary Education, 1970-2000 (percent); (e) Paid Employees Employed by the Private Sector as a Percentage of Total Employment, 1970-2000 (percent); (f) Paid Employees Employed by the Government as a Percentage of Total Employment, 1970-2000 (percent). 
(a)

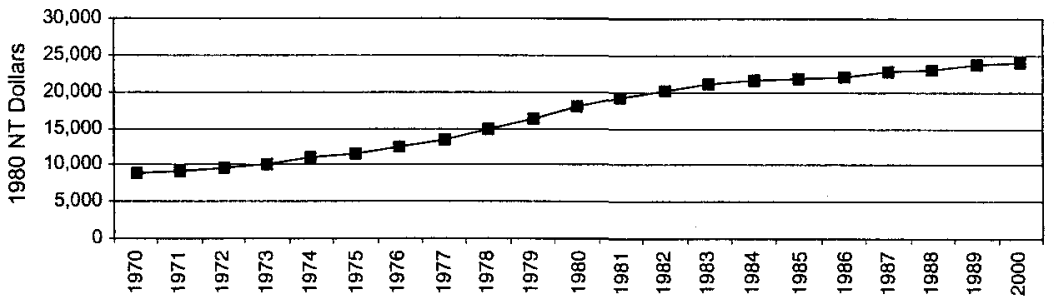

(b)

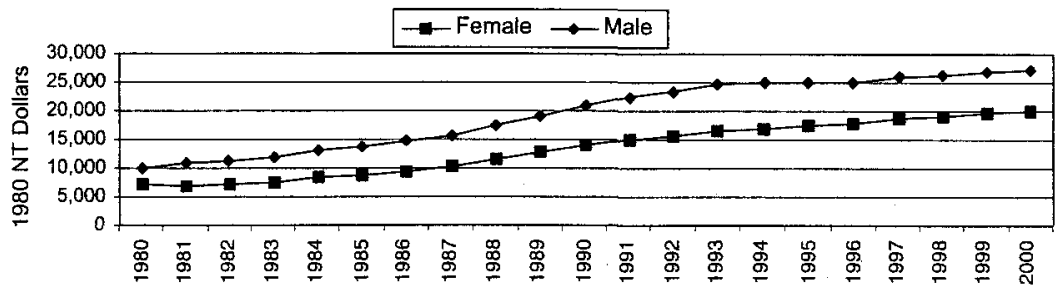

(c)

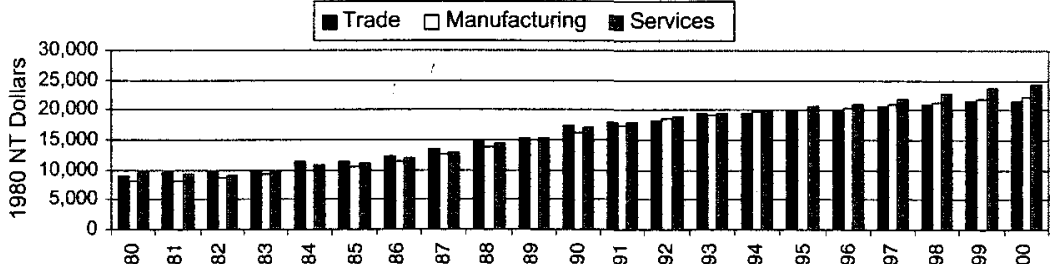

(d)

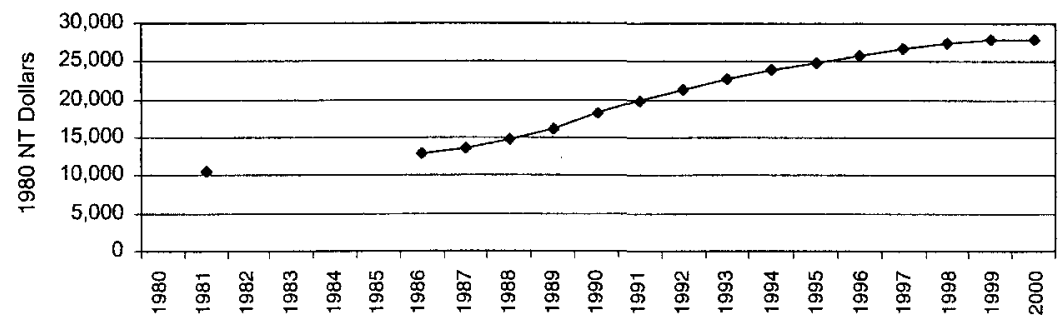

(e)

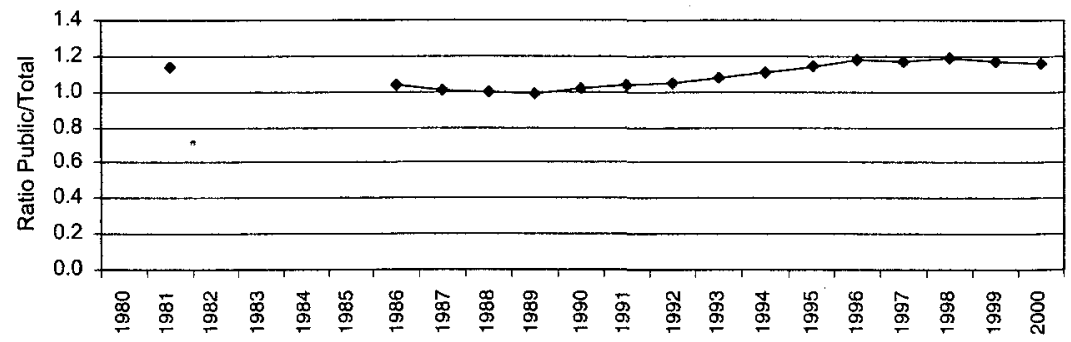

Figure 3A-4. Real Earnings. (a) Average Monthly Earnings of Employees in All Industries and Services, 1970-2000 (1980 NT dollars); (b) Average Monthly Earnings of Male, and Female Employees in All Industries and Services, 1980-2000 (1980 NT dollars); (c) Average Monthly Earnings by Sector, 1980-2000 (1980 NT dollars); (d) Average Monthly Earnings of Public Sector Employees, 1980-2000 (1980 NT dollars); (e) Ratio of Public Sector Earnings to Total Earnings, 1980-2000 (ratio public/total). 
(a)

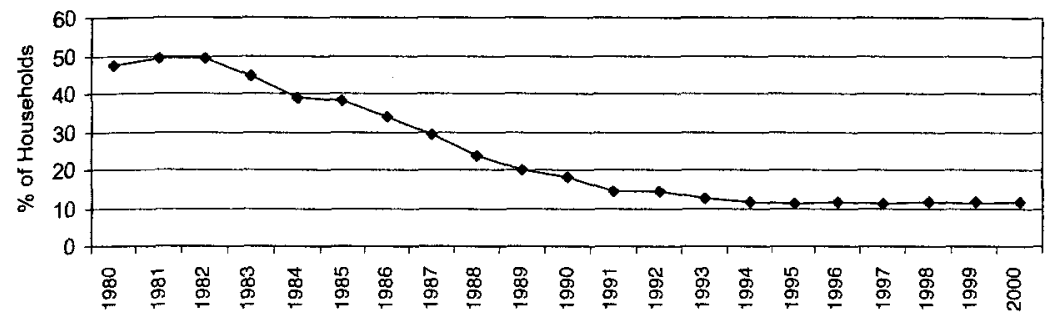

(b)

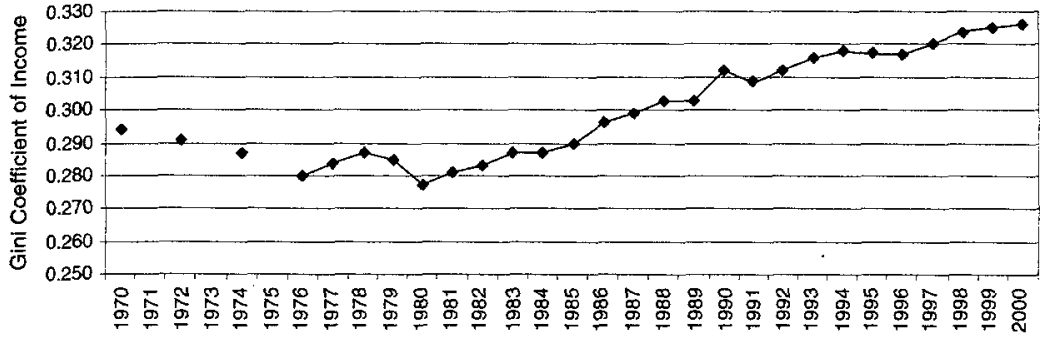

Figure 3A-5. Poverty and Inequality. (a) Poverty Headcount Ratio, 1980-2000 (percent of households); (b) Gini Coefficient of Inequality, 1970-2000 (Gini coefficient of household disposable income). 


\section{APPENDIX B. THE CASE OF INDONESIA}

Source: All figures for Indonesia are based on authors' calculations, drawing on the National Labor Force Survey (SAKERNAS), conducted by the Central Bureau of Statistics (BPS).

(a)

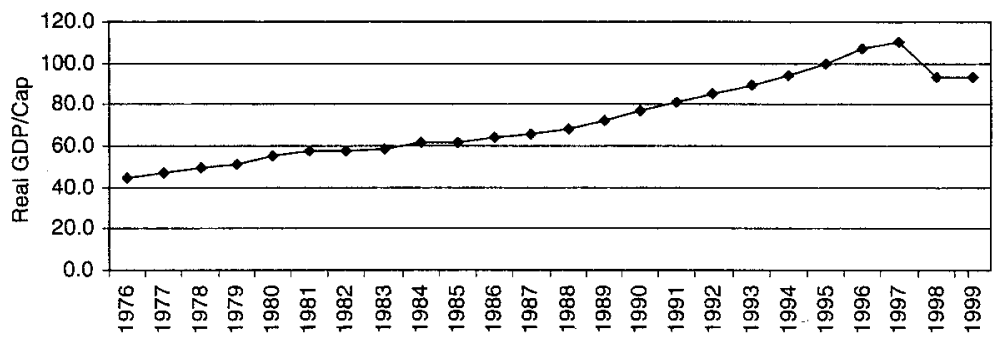

(b)

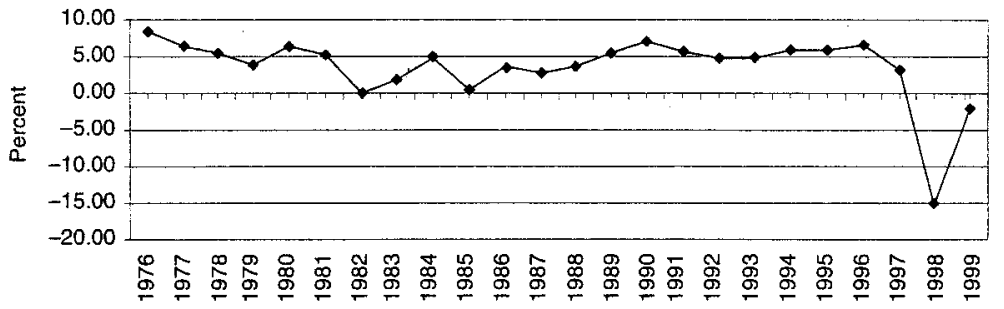

Figure 3B-1. Growth. (a) Level of Real GDP/Capita, 1976-99 (real GDP/capita); (b) Growth of Real GDP/Capita, 1976-99 (percent).

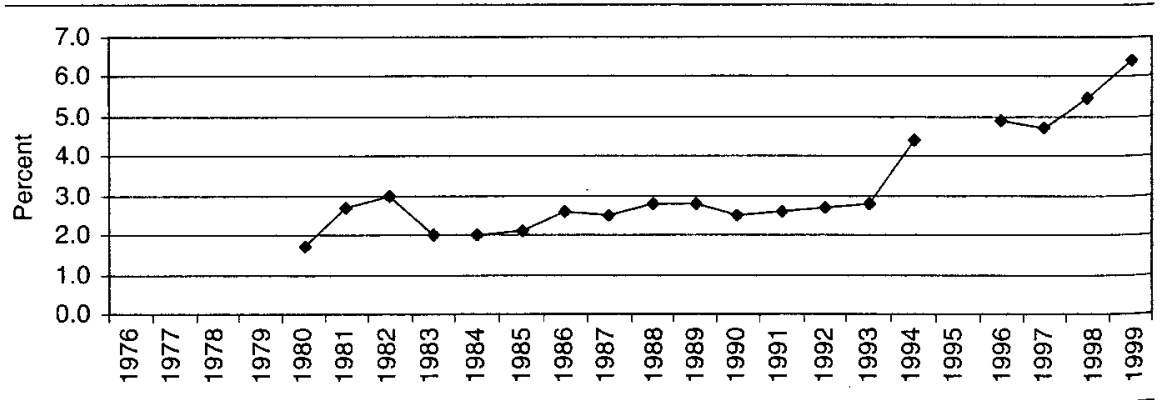

Figure 3B-2. Unemployment Rate, 1976-99 (percent). 
(a)

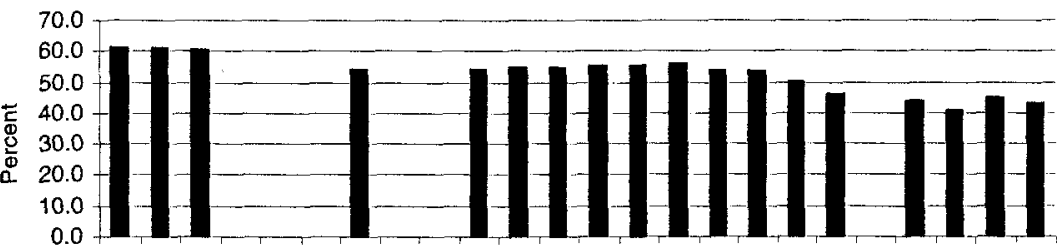

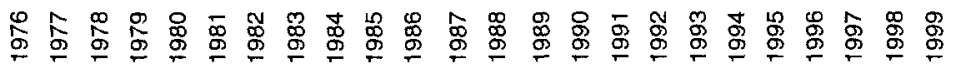

(b)

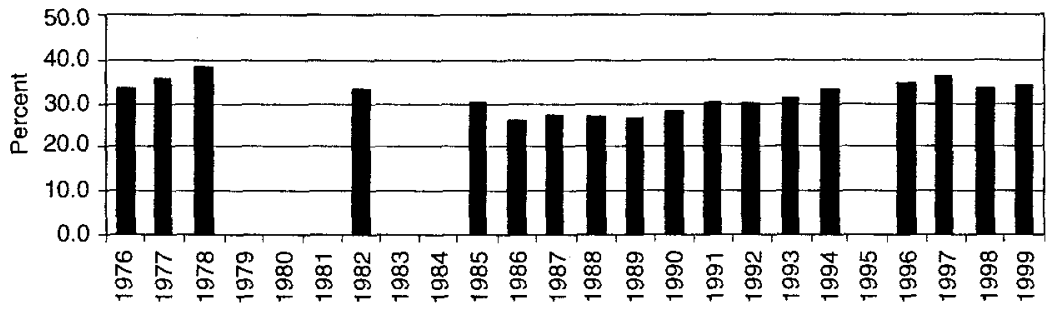

(c)

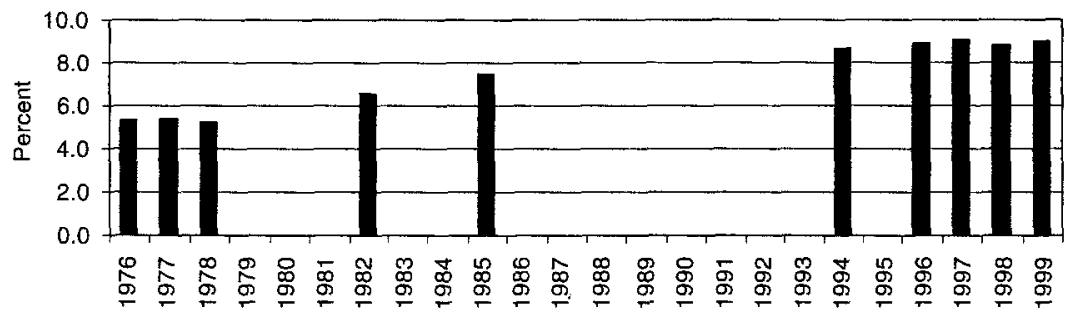

(d)

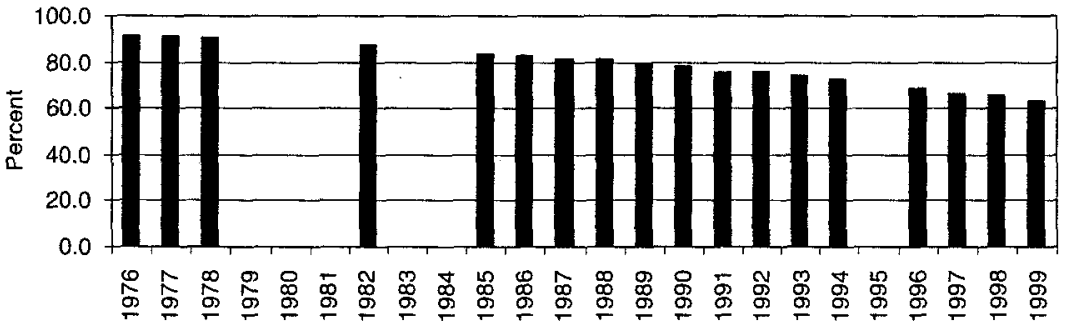

(e)

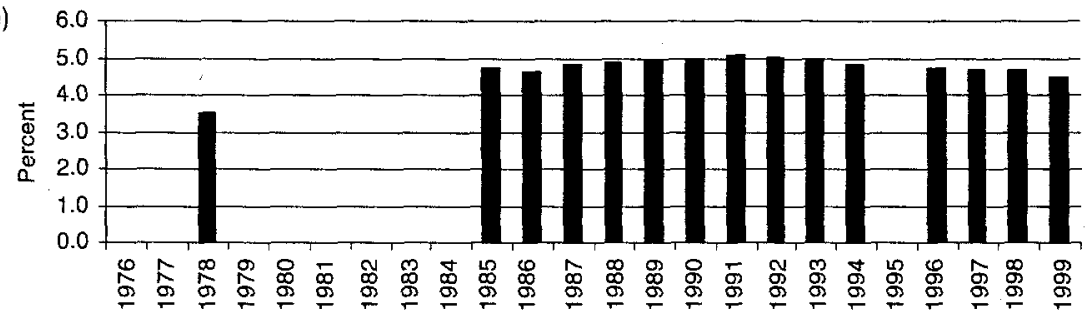

Figure 3B-3. Employment Composition. (a) Agricultural Employment as a Percentage of Total Employment, 1976-99 (percent); (b) Wage and Salaried Employees as a Percentage of Total Employment, 1976-99 (percent); (c) Professional Employees as a Percentage of Total Employment, 1976-99 (percent); (d) Percentage of Employed Persons with Less than a Secondary Education, 1976-99 (percent); (e) Percentage of Employed Persons Who Are Civil Servants, 1976-99 (percent). 
(a)

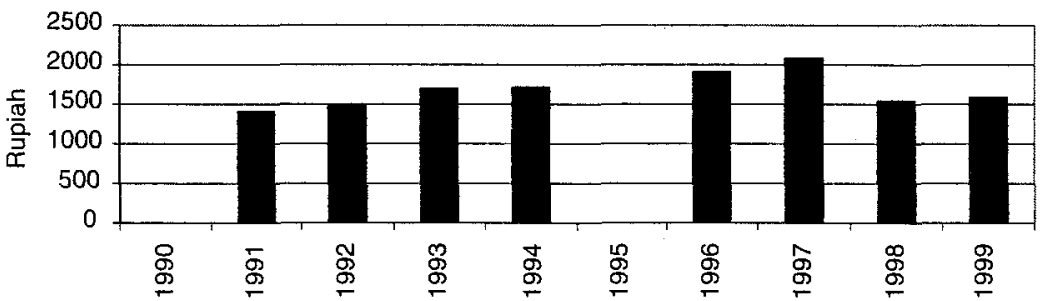

(b)

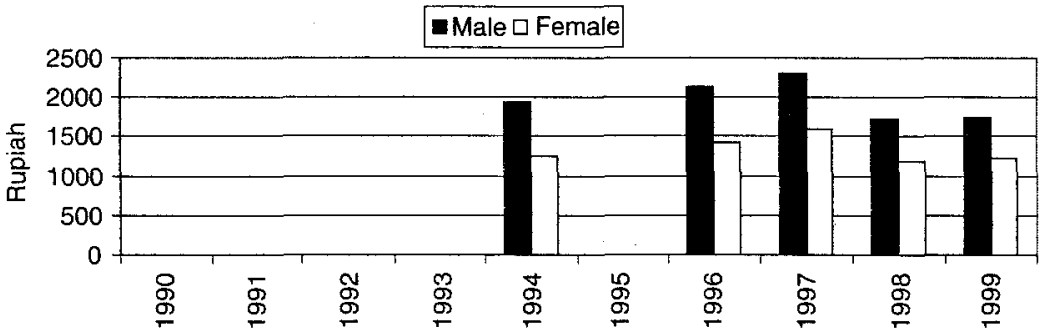

Agriculture $\square$ Manufacturing Trade

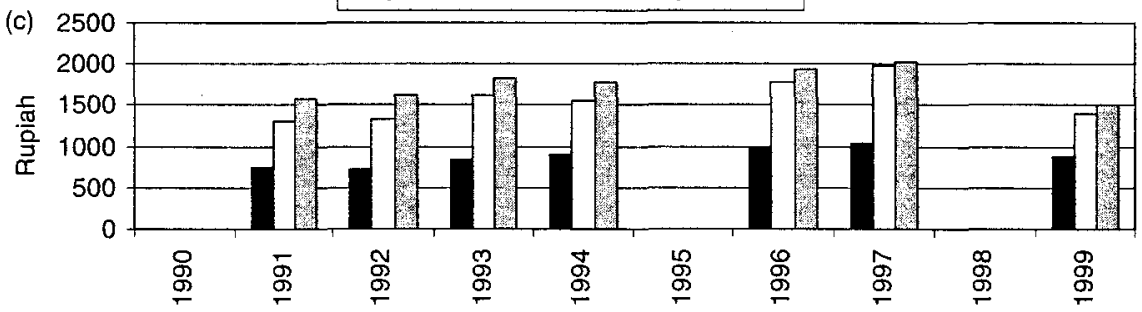

Figure 3B-4. Real Earnings. (a) Real Average Monthly Wage-net Salary of All Employees, 1990-99 (Rupiah); (b) Real Average Monthly Wage-net Salary of Employees by Gender, 1990-1999 (Rupiah); (c) Real Average Monthly Wage-net Salary of Employees by Main Industry, 1990-99 (Rupiah). 


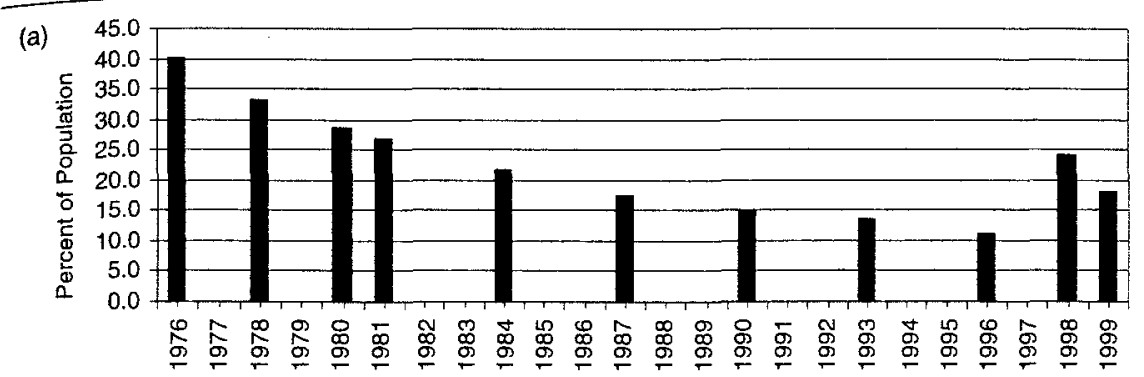

(b)

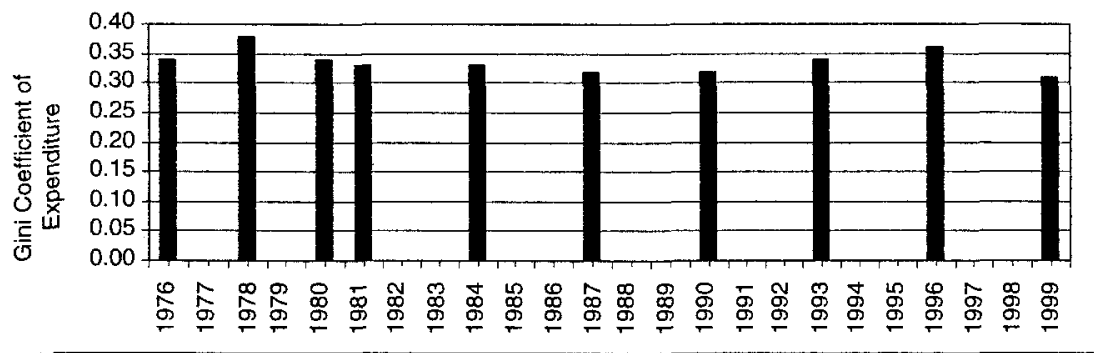

Figure 3B-5. Poverty and Inequality. (a) Poverty Headcount Ratio, 1976-99 (percent of population); (b) Gini Coefficient of Inequality, 1976-99 (Gini coefficient of expenditure). 


\section{APPENDIX C. THE CASE OF COSTA RICA}

Source: All figures for Costa Rica are based on authors' calculations, drawing on statistical data obtained from the household survey in Costa Rica, first called the Encuesta Nacional de Hogares, Empleo y Desempleo and later the Encuesta de Hogares de Propósitos Múltiples.

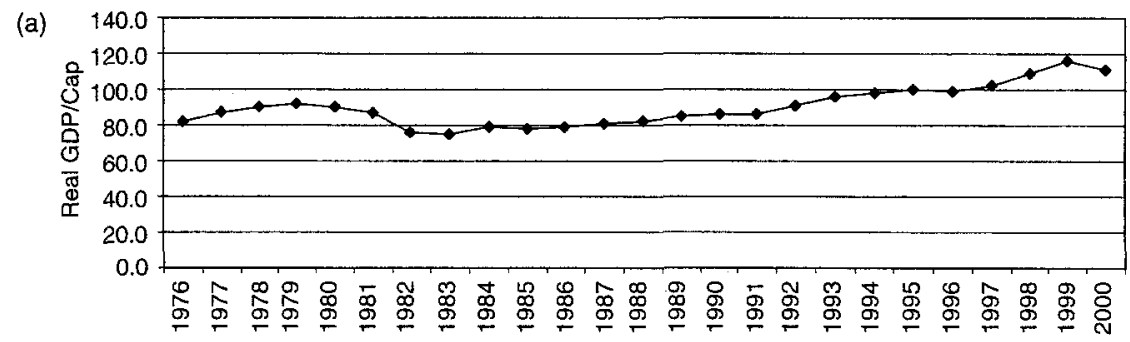

(b)

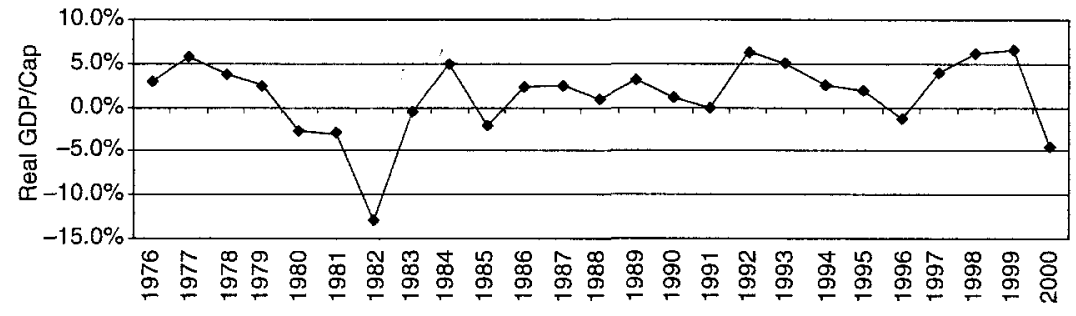

Figure 3C-1. Growth. (a) Level of Real GDP/Capita, 1976-2000 (real GDP/capita); (b) Growth of Real GDP/Capita, 1976-2000 (real GDP/capita).

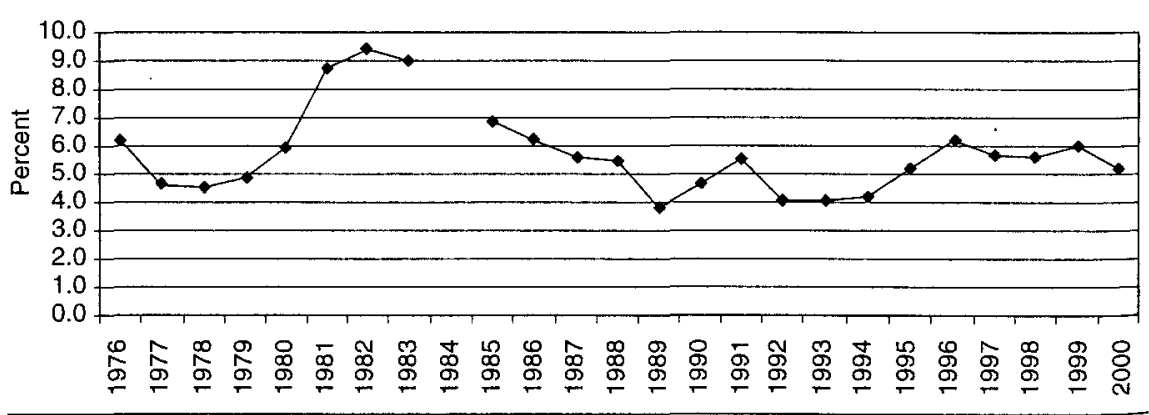

Figure 3C-2. Unemployment Rate, 1976-2000 (percent). 
(a)

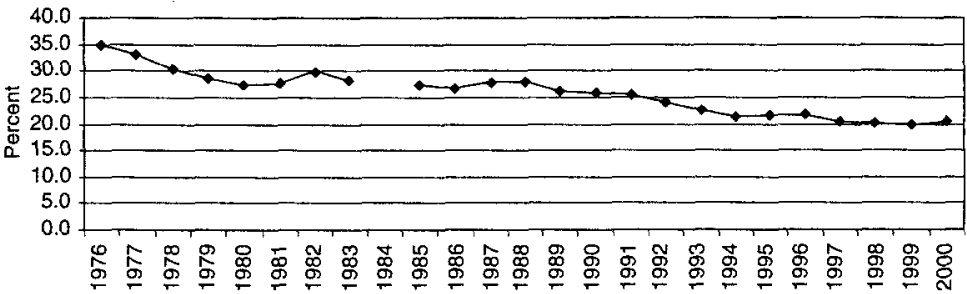

(b)

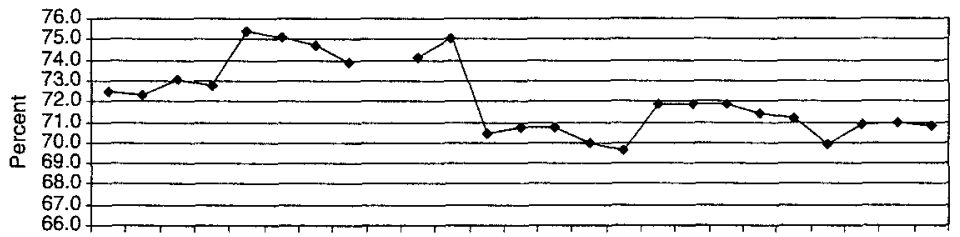

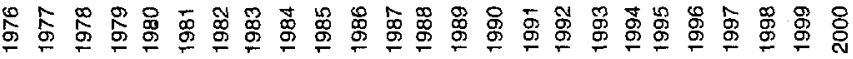

(c)

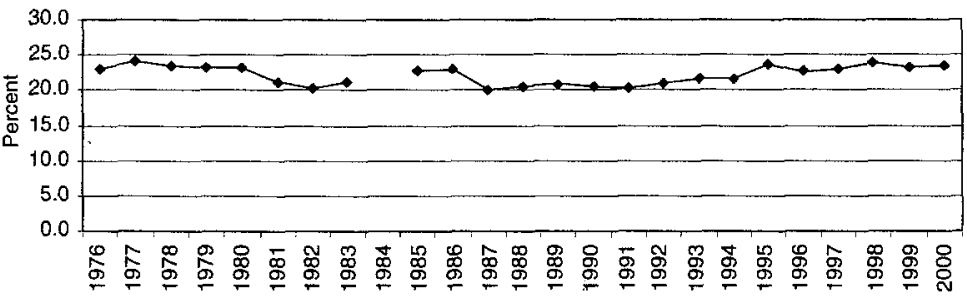

(d)

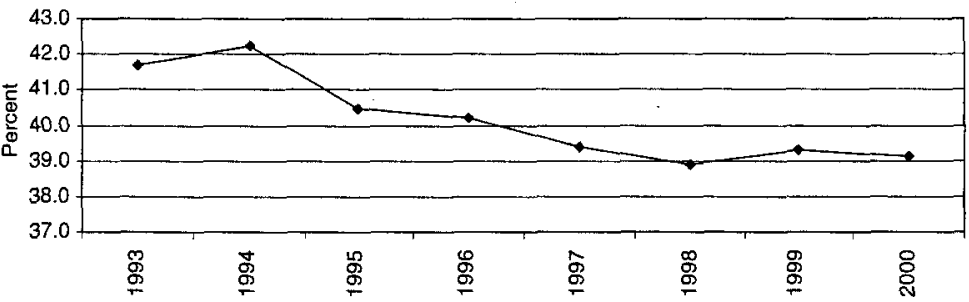

(e)

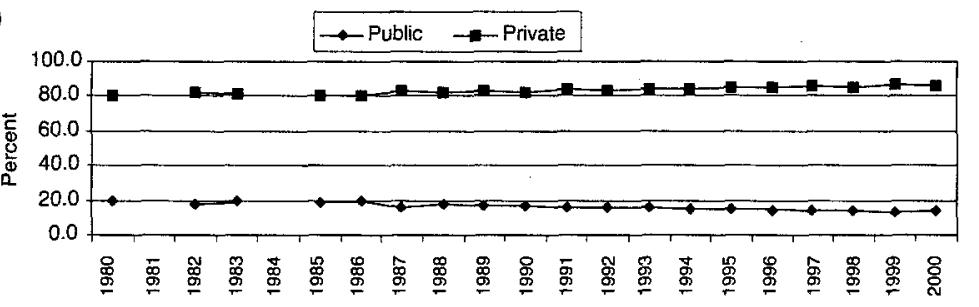

Figure 3C-3. Employment Composition. (a) Agricultural Employment as a Percentage of Total Employment, 1976-2000 (percent); (b) Wage and Salaried Employees as a Percentage of Total Employment, 1976-2000 (percent); (c) Professional Employees as a Percentage of Total Employment, 1976-2000 (percent); (d) Population Five Years or Older Who Have Not Completed Primary School, 1993-2000 (percent); (e) Percentage of Employed Persons by Public and Private Sector, 1980-2000 (percent). 
(a)

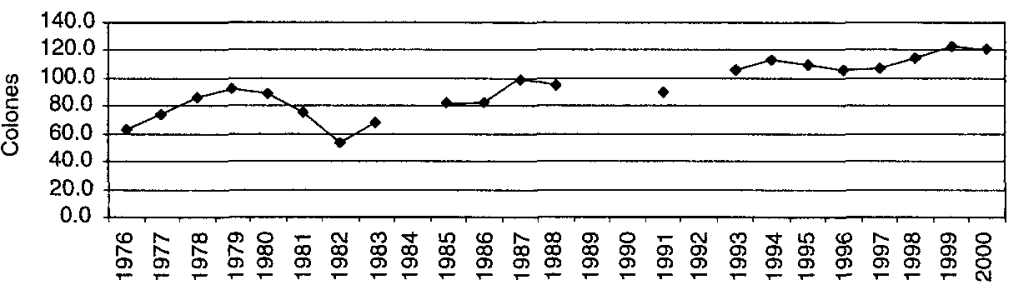

(b)

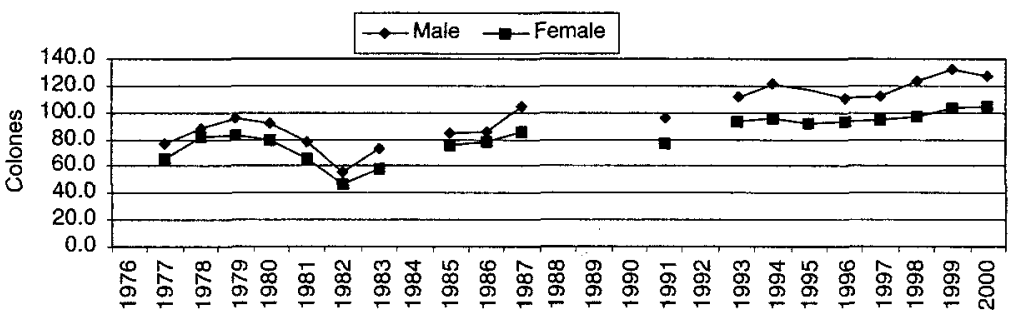

(c)

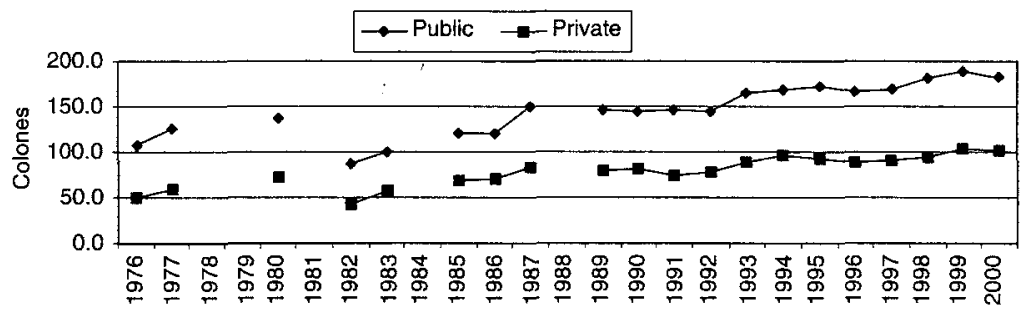

(d)

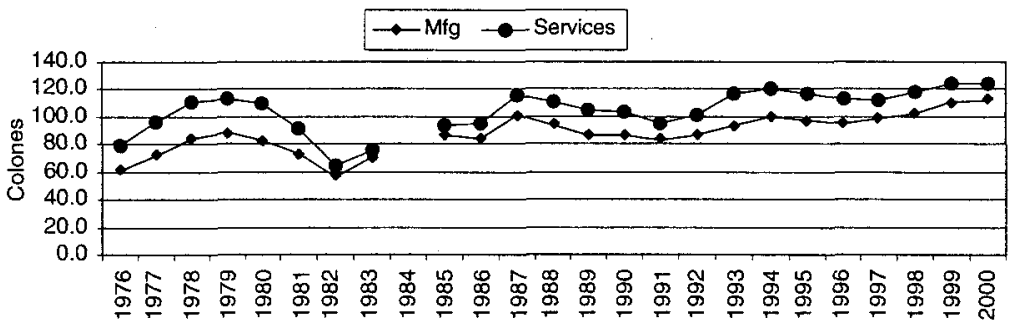

(e)

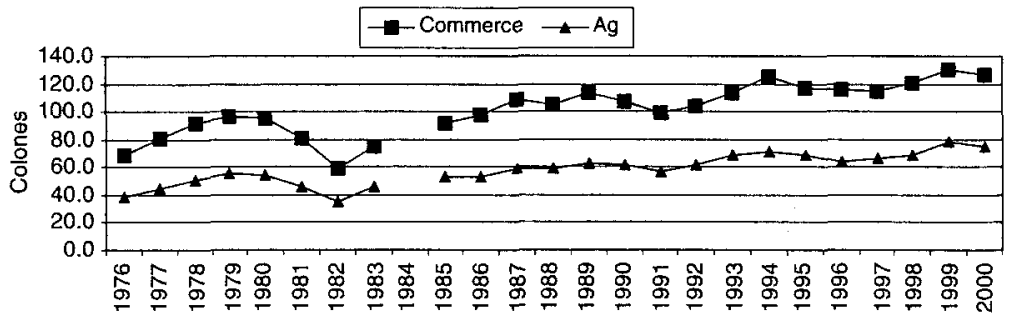

Figure 3C-4. Real Earnings. (a) Average Monthly Income of Employed Persons, 1976-2000 (Colones); (b) Average Monthly Income by Gender, 1976-2000 (Colones); (c) Average Monthly Income of Employed Persons in the Public and Private Sector, 1976-2000 (Colones); (d) Average Monthly Income of Employed Persons in the Manufacturing and Services Sectors, 1976-2000 (Colones); (e) Average Monthly Income of Employed Persons in the Commerce and Agricultural Sectors, 1976-2000 (Colones). 
(a)
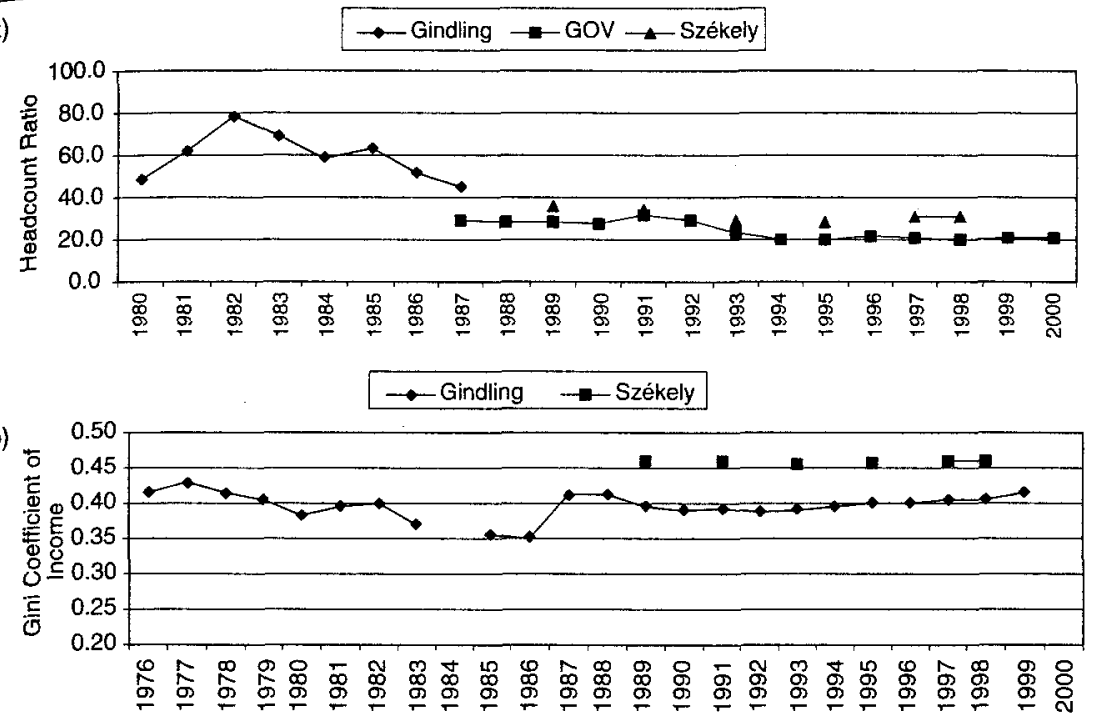

Figure 3C-5. Poverty and Inequality. (a) Poverty Headcount Ratio, 1980-2000 (headcount ratio); (b) Gini Coefficient of Inequality, 1976-2000 (Gini coefficient of income of paid salaried employees). 


\section{APPENDIX D. THE CASE OF BRAZIL}

Source: All figures for Brazil are based on authors' calculations, drawing on data on labor markets and income distribution derived from the Pesquisa Nacional Por Amostra de Domicilios (PNAD).
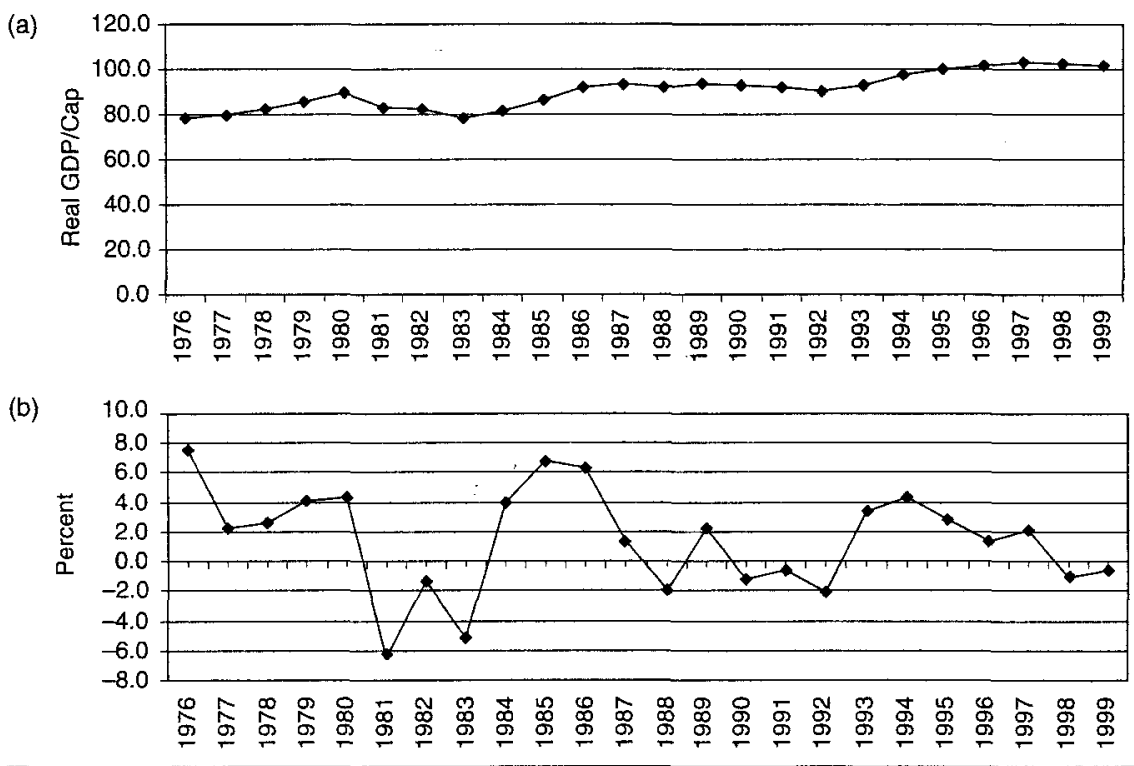

Figure 3D-1. Growth. (a) Level of Real GDP/Capita, 1976-99 (real GDP/capita); (b) Growth of Real GDP/Capita, 1976-99 (percent).

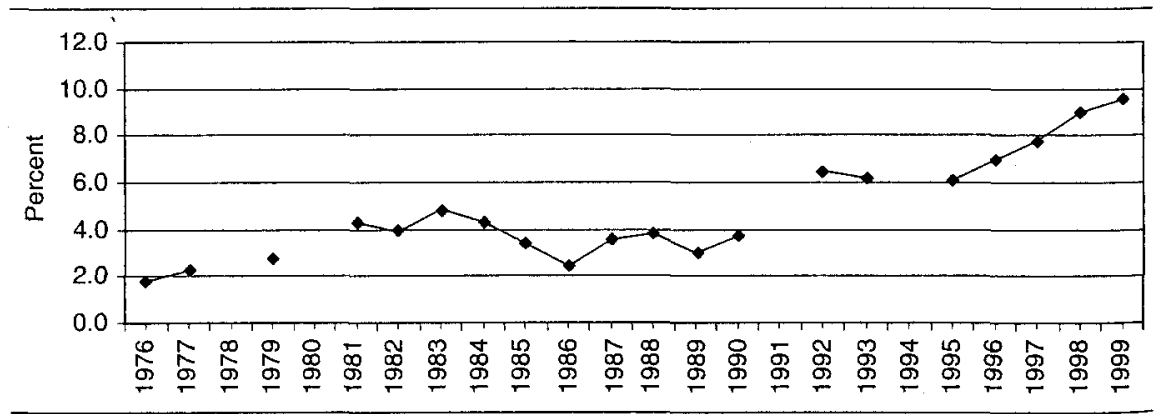

Figure 3D-2. Unemployment Rate, 1976-99 (percent). 
(a)

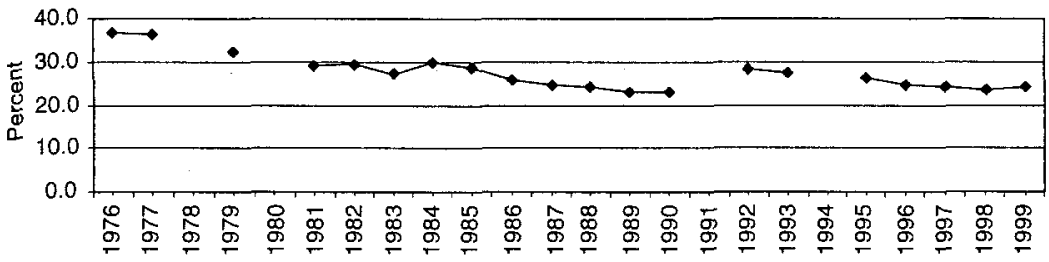

(b)

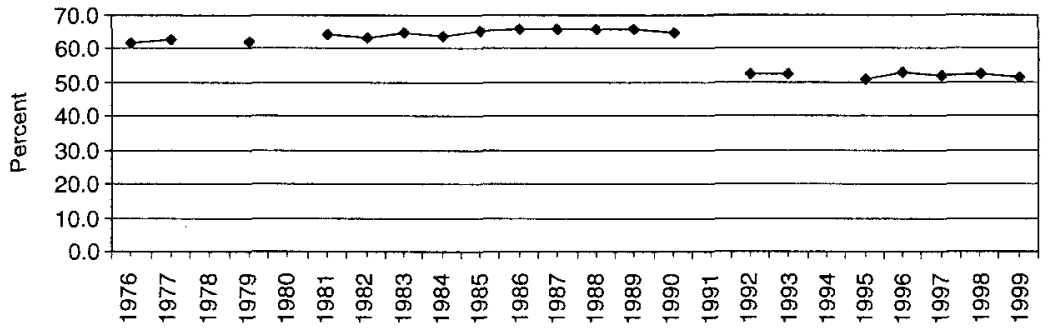

(c)

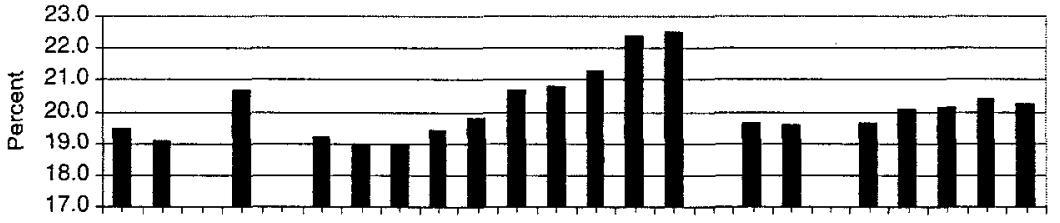

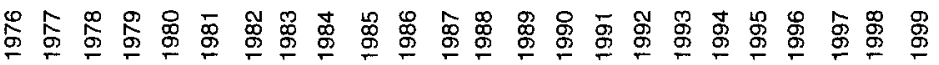

(d)

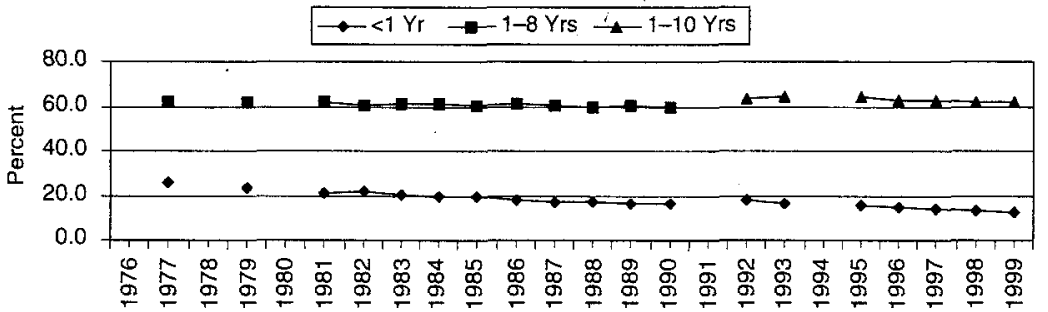

(e)

Formal Public $\square$ Formal Private Informal

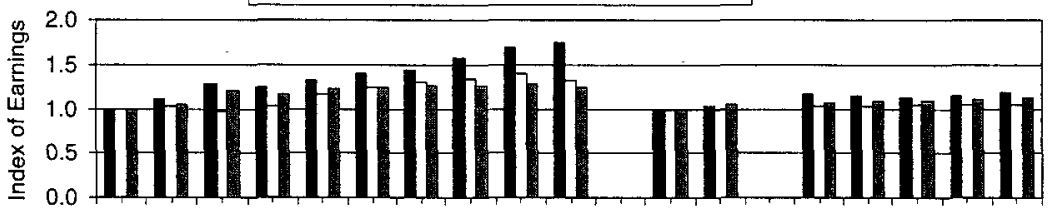

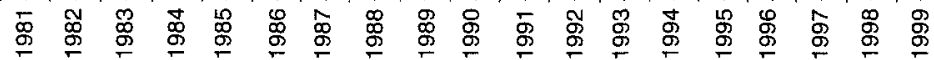

Figure 3D-3. Employment Composition. (a) Agricultural Employment as a Percentage of Total Employment, 1976-99 (percent); (b) Wage and Salaried Employees as a Percentage of Total Employment, 1976-99 (percent); (c) Professional Employees as a Percentage of Total Employment, 1976-99 (percent); (d) Percentage of Employed Persons by Years of Education, 1976-99 (percent); (e) Percentage of Employed Persons by Public, Private, and Informal Employment, 1981-99 (index of earnings). 
(a)

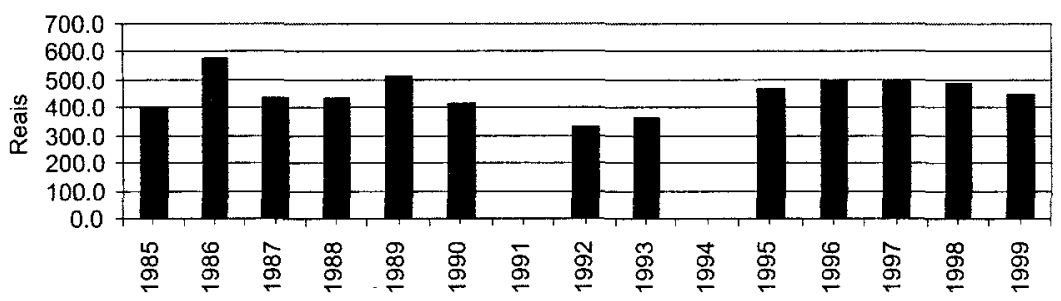

(b)

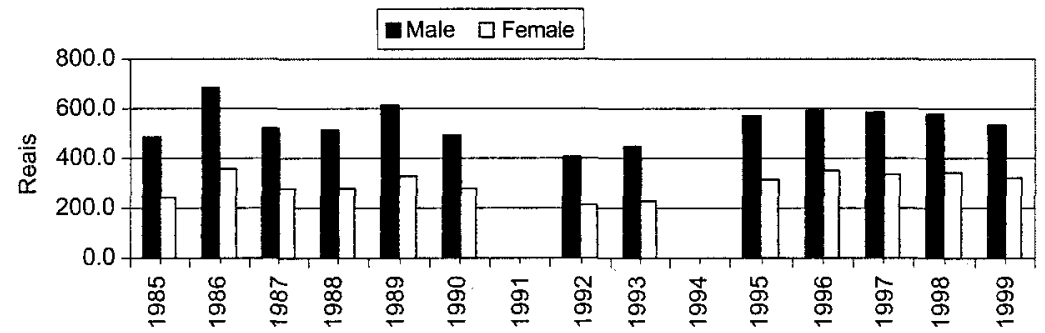

(c)

Formal Public. $\square$ Formal Private Informal

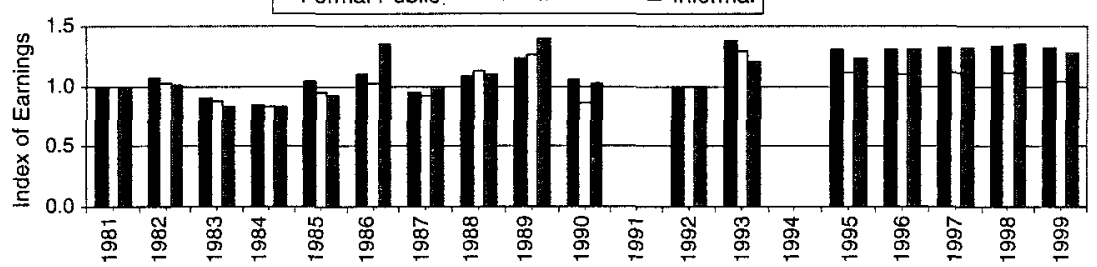

(d)

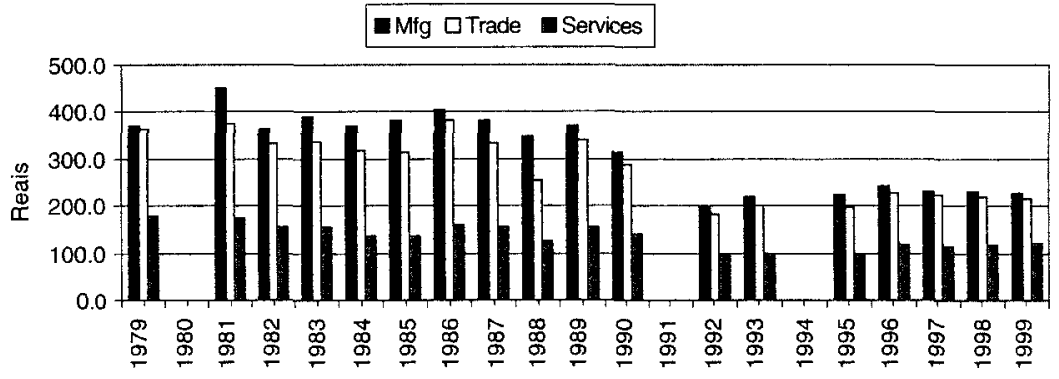

Figure 3D-4. Real Earnings. (a) Real Average Monthly Income of All Jobs of Employed Persons, 1985-99 (Reais); (b) Average Monthly Income of All Jobs of Employed Persons by Gender, 1985-99 (Reais); (c) Real Earnings of Employed People by the Public, Private, and Informal Sectors, 1981-99 (index of earnings); (d) Real Average Monthly Income of All Jobs of Employed Persons by Sector, 1979-99 (Reais). 
(a)

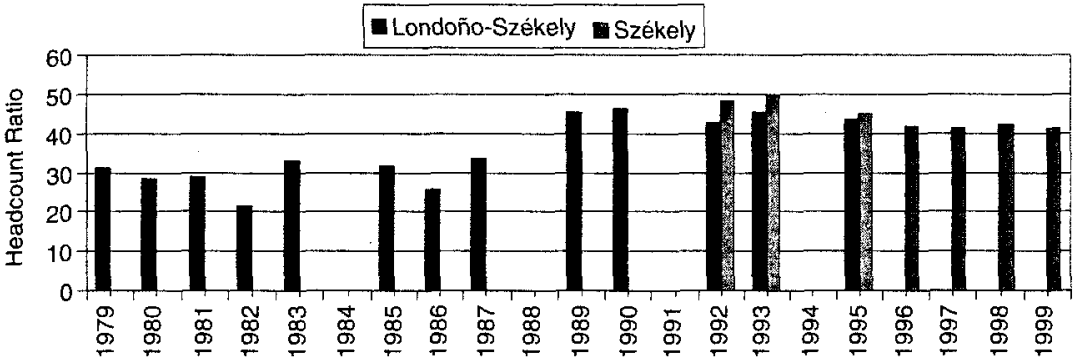

(b)

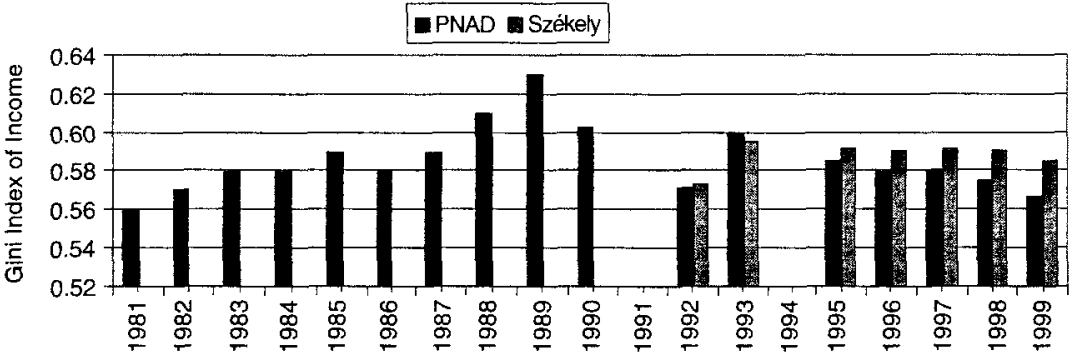

Figure 3D-5. Poverty and Inequality. (a) Poverty Headcount Ratio, 1979-99 (headcount ratio); (b) Gini Coefficient of Inequality, 1981-99 (Gini coefficient of income).

Note: "PNAD" data present the Gini coefficient of monthly income of all jobs for employed person 10 years of age and older who have work income. "Székely" data present the Gini coefficient of household per capita income.

\section{REFERENCES}

Bhagwati, Jagdish. 2002. "Coping with Antiglobalization." Foreign Affairs 81 (1): 2-7.

Dollar, David and Aart Kraay. 2001. "Growth is Good for the Poor." World Bank, Washington, D.C. Processed.

ECLAC (Economic Commission for Latin America and the Caribbean). 2001. Social Panorama of Latin America: 2000-2001. Santiago, Chile.

Fei, John C.H. and Gustav Ranis. 1964. Development of the Labor Surplus Economy. Homewood, Illinois: Irwin. Fields, Gary S. 1984. "Employment, Income Distribution, and Economic Growth in Seven Small Open Economies." The Economic Journal 94 (373): 74-83.

-. 1985. "Industrialization and Employment in Hong Kong, Korea, Singapore, and Taiwan." In Walter Galenson, ed., Foreign Trade and Investment: The Newly Industrializing Asian Countries. Madison: University of Wisconsin Press.

- 1994. "Changing Labor Market Conditions and Economic Development in Hong Kong, the Republic of Korea, Singapore, and Taiwan, China." World Bank Eronomic Review 8 (3): 395-414.

Fields, Gary S. 2001. Distribution and Development: A New Look at the Developing World. Cambridge, Mass.: MIT Press and the Russell Sage Foundation.

Fox, M. Louise, Edward Amadeo, and Jose Marcio Camargo. 1994. "Brazil." In Susah Horton, Ravi Kanbur, and Dipak Mazumdar, eds., Labor Markets in an Era of Adjustment. Washington, D.C: World Bank.

Galenson, Walter. 1977. "Economic Growth, Income, and Employment." Paper presented at the Conference on Poverty and Development in Latin America, Yale University, April. 
Gindin, Sam. 2002. "Social Justice and Globalization: Are They Compatible?" Monthly Review 54 (2): 1-7.

Gindling, T. H. 1991. "Labor Market Segmentation and the Determination of Wages in the Public, PrivateFormal, and Informal Sectors in San José, Costa Rica." Economic Development and Cultural Change 39 (3): 584-605.

Henwood, Doug. 1996. "Antiglobalization." Lefi Business Observer 71: 1-5.

IFC (International Finance Corporation). 2000. "Paths Out of Poverty."Washington, D.C.

ILO (International Labor Organization). 1999. “Indonesia Country Paper." Geneva, Switzerland.

Lewis, W. Arthur. 1954. "Economic Development with Unlimited Supplies of Labor." The Manchester School.

Londoño, Juan Luís, and Miguel Székely. 1998. "Sorpresas Distributivas Después de una Década de Reformas:América Latina en los Noventa." Pensamiento Iberoamericano. Revista de Economía Política (Special Issue), 195-242.

Rama, Martin, and Raquel Artecona. Forthcoming. "A Database of Labor Market Indicators across Countries." World Bank, Washington, D.C. Available at http://wbln0018.worldbank.org/LAC/ LACInfoClient.nsf/d29684951174975c85256735007fef12/ef45c359138c2df7852567fa00772cf1?Open Document.

Smith, James P., Duncan Thomas, Elizabeth Frankenberg, Kathleen Beegle, and Graciela Teruel. 2000. "Wages, Employment, and Economic Shocks: Evidence from Indonesia." Rand Corporation Working Paper DRU-2319-1-NICHD. Santa Monica, California.

Stern, Nicholas. 2001. "Globalization, the Investment Climate, and Poverty Reduction." Speech presented to the ICRIER, New Delhi, India, March.

Suryahadi, Asep, Sudarno Sumarto, Yusuf Suharso, and Lant Pritchett. 2000. "The Evolution of Poverty During the Crisis in Indonesia, 1996-99." World Bank Policy Research Working Paper 2435. Washington, D.C.

Székely, Miguel. 2001. "The 1990s in Latin America: Another Decade of Persistent Inequality, but with Somewhat Lower Poverty." Inter-American Development Bank, Washington, D.C.

Thomas, Duncan, Kathleen Beegle, and Elizabeth Frankenberg. 2000. "Labor Market Transitions of Men and Women during an Economic Crisis: Evidence from Indonesia." Rand Corporation Working Paper DRU-2344-NICHD/NIA. Santa Monica, California.

World Bank. 1990. World Development Report 1990. Poverty. New York: Oxford University Press.

- 1993. The East Asian Miracle. Washington, D.C.: World Bank. Press.

- 1995. World Development Report 1995. Workers in an Integrating World. New York: Oxford University - 2001. World Development Report 2000/2001. Attacking Poverty. New York: Oxford University Press.

\section{NOTES}

*The authors thank Guy Pfeffermann, William Maloney, and Carol Graham for helpful comments on an earlier draft.

'Inequality is another thing, however. Research on growth and inequality has clearly shown that there is no pattern, and that inequality increases with economic growth as often as it decreases (Fields 2001).

2"Globalization and Its Critics." The Economist, September 19, 2001, pp. 3--30. 